\title{
Community Empowerment through Management of Village Funds Allocation in Indonesia
}

\author{
Endang Hermawan \\ Universitas Pasundan, Indonesia \\ Email: endang.hermawan@gmail.com
}

\begin{abstract}
The purpose of this study is to explore how community empowerment is carried out by village governments through village funds in village Langen Sari, West Java, Indonesia. The community empowerment is realized through Village Fund Allocation (ADD). $30 \%$ of the Village Fund Allocation is used for operational costs of the Village Government and the Village Consultative Body (BPD), $70 \%$ for community empowerment, and strengthening the capacity of the Village Government. The research method used is descriptive research with a qualitative approach using Milles and Huberman's analysis methods. The results showed that the use of Village Fund Allocation for the community empowerment component was not yet on target. Community participation is a significant factor in launching community empowerment, while a lack of human resources and weak supervision are obstacles.
\end{abstract}

Keywords: management of village fund allocation, community empowerment

\section{A. INTRODUCTION}

Today the Indonesia government continues to strive to increase the implementation of National Development so that the pace of regional development and the speed of rural and urban development are more balanced and harmonious. However, at the level of implementation, it is still faced with the main problems of development, such as development inequality between villages and cities in Indonesia.

Development inequality occurs due to many factors that influence it so that development in Indonesia is uneven so that it impacts on high poverty in Indonesia. Related to the problem of poverty, according to BPS data, the number of poor people in 2016 city residents with a percentage of debt of $7.79 \%$, while poverty in rural areas amounted to $14.11 \%$. Responding to these problems, the government's strategy to overcome development inequality is to carry out national development, which places considerable attention on village development. The seriousness of the government can be seen in President Jokowi's third desire to build Indonesia from the periphery by strengthening regions and villages within the framework of a unitary state.

Village development has a vital and strategic role in the framework of National Development and Regional Development, because it contains elements of equitable development and its results and directly touches the interests of the majority of people who live in rural areas to improve their welfare. 
Regarding village development, the village government is located as a subsystem of the government administration system in Indonesia, so that the village has the authority, duties, and obligations to regulate and manage the interests of its own people. In doing so, village income sources are needed. Some things that cause villages need sources of income are:

1. Communities have a small Village Budget (APBDes), and the source of income is very dependent on very little assistance.

2. The welfare of the village community is low, so that it is difficult for villages to have high Original Village Revenues (PADes).

3. The problem was followed by the low operational funds of the town to run public services.

4. Many development programs enter the village but are only managed by the department. Such programs gain criticism because the program does not provide access to learning for the town, and the program is top-down, so it is not in line with the needs of the village and its people.

Responding to these problems, the government provides financial support to villages, one of which comes from the Financial Balance fund between the Central Government and the Regional Government of at least 10\% intended for communities called the Village Fund Allocation (ADD). The purpose of giving ADD is actually as a stimulant aid or stimulant fund to encourage in funding the village government program, which is supported by the participation of community mutual assistance in carrying out government activities and community empowerment.

Based on Cianjur Regent Regulation No. 5 of 2015 concerning Guidelines for Management of Village Fund Allocation for Cianjur Regency in 2015, details of the use of $\mathrm{ADD}$ are $30 \%$ for the village government, which is used for operational costs, benefits, official travel costs from the village government. While $70 \%$ of the use of ADD is for community empowerment and strengthening the capacity of the Village Government. From the details of the use of ADD, there needs to be proper management from the village government so that the implementation is by the aims and objectives of ADD. The Village Fund Allocation Manager in the village is the Village Head, the Village Financial Management Technical Implementation (PTPKD), and the Village Treasurer is expected to understand and understand the Village Fund Allocation management. In the process of managing the Village Fund Allocation in Langensari Village, Karangtengah Subdistrict, Cianjur Regency, the village government is confronted with the condition of the level of education of the people who are still weak.

This is by the population data based on education in 2015, namely: 655 residents did not graduate from school, 2100 residents graduated from elementary school, 1605 residents graduated from junior high school, 1150 residents graduated from high school, and only 125 residents graduated from academy or college. Based on the 
previous pre-research, this research has the aim to describe and analyze the Management of Village Fund Allocation in empowering village communities, the driving and inhibiting factors in the management of the Village Fund Allocation in empowering village communities in Langensari Village, Karangtengah Subdistrict, Cianjur Regency.

\section{B. METHOD}

This type of research used in this study is a qualitative study with the approach used is a descriptive approach. Data collection techniques are done using interviews, observation, and documentation. Data analysis in this study uses the method of analysis by Milles and Huberman in Sugiyono (2009:16), which includes data reduction, data presentation, and concluding. In this study, the location of the survey was Langensari Village, Karangtengah District, Cianjur Regency. The focus in this research is: first, the management of the Village Fund Allocation (ADD) in empowering village communities, which consists of:

1. ADD planning;

2. ADD budgeting;

3. ADD and disbursement mechanism;

4. Use of ADD;

5. ADD supervision;

6. ADD liability.

Second, supporting factors and obstacles in the management of the Village Fund Allocation in empowering village communities. To analyze the problem in this study, the writer uses several relevant theoretical concepts. Among them is the idea of Village Fund Allocation. According to Government Regulation Number 43 of 2014 concerning Implementing Regulation of Law Number 6 of 2014 concerning Villages that the Village Fund Allocation is a balanced fund received by the district/city in the district/city Regional Revenue and Expenditure after deducting the Special Allocation Fund. ADD is included in Village Financial Management, according to Regulation of the Minister of Home Affairs Number 113 of 2014 concerning Village Financial Management in article 1, explaining that Village Financial Management is the whole activity which includes planning, implementing, administering, reporting, and accountability of village finances. The principles of Village Financial Management in the Minister of Home Affairs Regulation Number 113 of 2014 concerning Village Financial Management, are: transparent, accountable, participatory, and carried out in an orderly and budgetary discipline.

The objectives are: 1) Reducing poverty and reducing inequality. 2) Improve development planning and budgeting at the village level and community empowerment. 3) Increase rural infrastructure development. 4) Increase the practice of 
religious values, social culture to realize social improvement. 5) Improve public order and order. 6) Improve services to rural communities in the context of developing social and economic activities of the city. 7) Encourage increased self-help and community cooperation. 8) Increase village and village community income through Village-Owned Enterprises (BUMDesa). The use of ADD refers to the Cianjur Regent Regulation Number 5 of 2015 concerning Guidelines for the Management of Village Fund Allocation for Cianjur Regency in 2015

The next concept is the Community Empowerment. According to Wahjudin Sumpeno (2011: 19), empowerment is an effort made by elements from outside the order of an order, so that the law can develop independently. In other words, empowerment as an effort to improve the form of interconnection contained in an order and efforts to enhance the elements or components that are intended so that the law can develop independently. So empowerment is an effort aimed at a request to achieve a condition that is possible to build itself. According to Sumaryadi (2005: 25) the purpose of community empowerment is basically to help develop authentic and integral human beings from weak, sick, marginal and small people and empower these social groups economically so that they can be more independent and can meet the needs the basis of their lives, but able to participate in community development.

\section{RESULT AND DISCUSSION}

\section{Management of Village Fund Allocation (ADD) in Village Community Empowerment}

a. ADD planning

ADD planning is done by capturing the aspirations and needs of the community through village consultations or village meetings. In the Langensari village, a village discussion was held to discuss the Village Budget and Village Budget (APBDesa) planning, as well as the Village Development Planning Meeting (Musrembangdes), so that a Fund Utilization Plan (RPD) was produced. ADD planning in Langensari village is carried out with participatory planning through village deliberations.

The results showed a high level of community participation in holding village meetings could be seen from the level of attendance and the number of proposals by the community. The phenomenon in the field is by the theory of empowerment by Ife in Suharto (2005: 59), which explains that community empowerment can be seen from defining needs, namely the ability to determine needs in line with their aspirations and desires. Community empowerment can also be seen from the definition of ideas and ideas, namely the ability to express and contribute ideas in a forum or discussion freely and without pressure. 


\section{b. ADD Budgeting}

ADD budgeting is done after the results of the village deliberations are approved by all parties involved in the village, so that a Fund Utilization Plan (RPD) can be prepared for one year. The RPD includes the use of ADD Langensari Village funds in the amount of Rp. 105,000,000 for community empowerment and village government operations.

The Langensari village RPD, if examined, will find that the design is not by the provisions, where funds for the operation of the Village Consultative Body (BPD) are not included in the village government's Operational RPD. But the BPD operational funds are actually included in the community empowerment RPD. This phenomenon actually contradicts the Cianjur Regent Regulation Number 5 the Year 2015 concerning Village Fund Allocation Guidelines for the Management of Village Fund Allocation for Cianjur Regency in 2015 and Minister of Home Affairs Regulation Number 113 the Year 2014 concerning Village Financial Management. In both regulations, it is stipulated that the use of the ADD budget is 70\% for Community Empowerment and 30\% for the Operational Costs of the Village Government and BPD.

c. Disbursement and channeling mechanism ADD

The mechanism for disbursement and distribution of ADD, technically there are several stages that must be passed, namely as follows: after all the ADD submission files are complete, and in the submission file know the camat, then together from 19 villages in Karangtengah Sub District submitted to the Governance Section of the Village Secretariat Cianjur Regency. Then the Village Administration Section in the Cianjur District Secretariat will forward the application file and its attachments to the Head of the Revenue, Financial and Asset Management Agency (DPPKA). When all requirements have been met, the DPPKA immediately transfers ADD funds to the Langensari village PTPKD account. The mechanism for channeling and disbursing ADD in Langensari village is by regulations governing village financial management, namely Minister of Home Affairs Regulation No. 113 of 2014 concerning Village Financial Management.

d. Use of ADD

The use of ADD for community empowerment in Langensari village is Rp. 105,000,000. In the field of poverty alleviation, the use of funds is used for operational costs of distributing poor rice, house renovation programs, and pasteurization programs.

This is an achievement of community empowerment with a primary tendency. Based on the theory of empowerment by Pranaka and Vindhayanika in Prasojo (2003: 12), interior trends are empowerment processes emphasized in 
the process of giving or transferring some of the power, power, and ability to the community or individuals to become more empowered. In terms of increasing village income, Langensari Village does not yet have a Village-Owned Enterprise (BUMDes), the ADD allocation also has no budget for establishing BUMDes.

The use of funds to improve health status is to assist Integrated Service Posts (Posyandu). Where these costs are allocated to finance the activities of posyandu toddlers and elderly posyandu, this is by the theory of empowerment by Ife in Suharto (2005: 59), which explains that empowerment can be seen from the ability about the process of birth and child care. Based on the theory of community empowerment by Ife in Suharto (2005: 55) which explains that community empowerment can be done by increasing the ability to reach, use and influence community institutions such as social welfare institutions, education, health.

In the field of education, the use of ADD funds to increase knowledge outside school is to assist with operational teaching and learning activities for Kindergarten and Early Childhood. Utilization is actually appropriate, but too little allocated funds are a weakness in improving the quality of education. This is by the latest education level of the Langensari villagers, who are mostly elementary and junior high school graduates. It would be nice if the village government increased the budget for education and used the funds to support educational activities other than schools such as the Qur'an Education Park (TPQ) as well as the education and training of farmer groups.

Based on the theory of community empowerment by Widjaja (2004: 169) which explains that the way to empower people, especially in rural areas is not enough just to increase productivity, provide equal business opportunities or provide capital, but must also be followed by changes in the socio-economic structure of society.

Responding to community empowerment, Langensari village allocated ADD funds for community empowerment in the field of social and economic improvement of the community by increasing the role of women through the realization of gender equality and Empowerment of Family Welfare (PKK) Village. In encouraging the social and economic improvement of the community can be done through the activities of the PKK, which aims to increase family income with independence.

The phenomenon on the ground shows that there is still a gender gap in the political field where there is no involvement of women in government in Langensari village. According to Prasojo (2003: 13), Community empowerment is not only concerned with economic aspects. There are various kinds of empowerment, among others: empowerment in the political field, legal field, 
social field, cultural field, ecology field, and spiritual field empowerment. If it is related to the empowerment theory in Langensari village, there is no visible empowerment in politics and law funded by ADD whereas empowerment in the social, cultural, and spiritual fields is carried out by allocating ADD funds to increase the practice of religious life in the context of increasing social piety and preservation of mutual cooperation and self-sufficiency.

Based on the results of research on community empowerment in religion, funds raised from ADD can be said to have been appropriately used. Other efforts of the village government in empowering the community are allocating funds for a social sector that is focused on fostering youth through youth organizations and family development. In its utilization, the use of the budget is actually appropriate. Still, in its implementation, the activities of the youth cadets are only active once a year, namely on the anniversary of the Republic of Indonesia, and members of the youth group are only as a committee in organizing the competition.

This is not an actual youth empowerment effort; it should be used for youth funding for education and training as well as family development in increasing the social sensitivity of adolescents, arts, cultural preservation, and prevention of juvenile delinquency (drugs, street children). In contrast, the ADD budget for religious affairs is used to improve religious facilities and infrastructure.

Empowerment in the field of culture, Langensari village budgeted part of the ADD funds used to support the learning of mutual assistance and community self-reliance. Based on the results of the study it was found that the culture of bilateral cooperation and the community is very high, it can be seen when there are community service activities in building the houses of the unfortunate recipients of housing renovation programs funded by ADD.

The allocation of ADD in Langensari village in the development of village infrastructure to support the acceleration of community empowerment. In its use, the rural development budget is intended for the construction and maintenance of small scale public facilities and infrastructure such as roads, irrigation channels. The use of funds for rural infrastructure development is in accordance with the opinion of Widjaja (2004: 169) which explains that supporters of the development of community potential through increased roles, productivity and efficiency as well as improving access to 4 namely access to resources, access to technology sources, access to markets, and access to sources of financing.

The use of ADD to improve the stability of security, peace, and order of the community is allocated part of the funds for the operational assistance of the 
Community Protection Unit (Linmas) while the efforts of the village government in developing remote areas that have potential as well as for the development and socialization of Appropriate Technology (TTG) and utilization of village resources, as well as environmental preservation have not yet been seen, with no allocation of ADD funds for these two fields.

This is contrary to the principle of community empowerment regulated in the Regulations of the Regent of Cianjur District Number 5 of 2015 concerning Guidelines for the Management of Village Fund Allocation for Cianjur Regency in 2015, that the use of funds in empowerment includes for the development of remote areas that have potential as well as for the event and correcting of Appropriate Technology (TTG) and utilization of village resources, and environmental preservation.

The use of ADD in Langensari village has had a positive impact on increasing community cooperation and in the construction of village infrastructure. However, the adverse effects arising from the existence of the ADD program, such as the emergence of village dependence on these funds, so that village government efforts to obtain their own financial resources gradually disappear.

Management of ADD in Langensari village has been running well even though in various fields, the use of ADD is still not optimal. This can be seen from the ADD program which has been running since 2007, but has not shown maximum results such as high poverty, low education levels, no increase in Village Original Revenue (PADes), not yet formed Village Owned Enterprises (BUMDes) and also not yet optimal self-sufficiency from the community.

e. ADD supervision

Supervision is carried out on the course of government and development so that the implementation does not deviate from the predetermined plans and applicable rules based on phased physical implementation and financial management.

Functional management oversight of ADD, that is supervision by the supervisory apparatus or government unit of Cianjur Regency and Karangtengah District, which conducts control. Based on the observations of researchers, functional guidance in Langensari village in the form of reporting that should be done every month (Periodic Reports) and at the end of the year (SPJ) is only done three times a year. If related to regulations governing the supervision of ADD management, namely Regulation of the Minister of Home Affairs Number 113 of 2014 concerning Village Financial Management, article 44 explains that the provincial government is obliged to foster and oversee the distribution and distribution of Village Funds, Village Fund Allocation, and Tax 
Sharing and Regional Retribution from the Regency / City to the Village whereas the regency and sub-district governments are obliged to foster and oversee the implementation of village financial management.

Based on the phenomenon in the field, supervision by the Provincial, Regency, and Camat Governments that occur in the management of ADD in Langensari village is by applicable regulations. But it still needs to be improved.

Supervision is inherent, namely, monitoring carried out by direct superiors through the organizational structure, organizational chart with a strict range of control with the division of tasks and functions along with a clear job description. The researcher saw that the supervision attached to the Langensari village had been carried out by the Village Head, the village apparatus, and the respective chief executive of the activity. Based on the results of the study, there has not been any direct supervision by the community in the management of ADD. This happens due to the lack of public understanding of the ADD program so that there is a need for socialization and transparency about the use of ADD funds from the village government.

f. ADD liability

Accountability is a consequence of the use of public funds entrusted to the village government. Judging from the form of responsibility in Langensari village tends to be administrative.

Administrative responsibility is the responsibility of the village government for the organizational implementation of ADD activities in the form of the Letter of Responsibility (SPJ) for the supervision of Karangtengah SubDistrict Head to Cianjur District Head through the Governance Section of the Cianjur Regency Regional Secretariat Village. According to the Minister of Home Affairs Regulation No. 113 of 2014 concerning Village Financial Management, that accountability is delivered in the form of reporting on the results of the management of ADD. Reporting is done in the first semester no later than July and the end of the year, not later than January of the following year (Article 37). Implemented structurally from the Village Head to the Sub-District Head, then the Sub-District Head is forwarded to the Regent (Article 41). But in practice, the accountability of ADD to the Langensari village is only done once a year, at the end of the ADD year.

Based on the observation of researchers that there has not been direct accountability to the community. This happens because there is no transparency or openness by the village government as the manager of ADD to the community in the form of information on the use of ADD funds. Whereas Article 40 explains that the realization report and the accountability report on the implementation of 
the APBDesa are informed to the public in writing and with media information that is easily accessed by the public.

This analysis is also supported by the fact that the implementation of physical activities funded by ADD was handed over to the hamlet head or village apparatus, but in its application, never informed the community about the funds it received.

The above fact is contrary to the provisions in Cianjur District Regulation Number 5 of 2015 concerning Fund Allocation, that activities originating from ADD must be directly accountable to the community and BPD and the implementation of ADD must be carried out Participatively, Transparent and Accountably.

2. Supporting and Inhibiting Factors in the Management of the Village Fund Allocation (ADD) in Village Community Empowerment

a. Supporting elements

One of the supporting factors in the management of ADD is community participation. From observations made in Langensari village, it is illustrated that the level of community participation in the planning process in the implementation of ADD is quite high.

The high level of community participation in ADD planning in village meetings can be seen from the high level of attendance and the number of proposals by the community. The senior community participation in the management of ADD in Langensari Village is in accordance with the theory of empowerment according to Wahjudin Sumpeno (2011: 19) which explains that empowerment can be in the form of ideas and ideas, namely the ability to express and contribute ideas in a forum or discussion freely and without pressure.

Based on the results of research and observations that have been made, the culture of community cooperation is one of the driving factors in the management of ADD in Langensari village. The high culture of community cooperation can support the management of ADD, especially at the activity implementation stage. This is by the theory of empowerment by Wahjudin Sumpeno (2011: 19), which explains that empowerment is an effort aimed at making an order to achieve a condition that is possible to build itself.

b. Obstacle factor

The inhibiting factor in ADD management in Langensari village is the low level of human resources. Human resources of the small population of the town can be seen from the level of education of the majority of the community, namely elementary school graduates, while the village apparatus own the majority of 
junior high school graduates. This has an impact on the ADD stage of the management activities.

The planning process of ADD Desa Langensari implements a village consultative system. In the implementation, it seems that community participation is high, but the proposed forms of community activity tend to be physical development such as road works, irrigation, and others. Though these activities are not empowering the community themselves

The monotonous mindset of the city is planning for the use of ADD funds is a reflection of the lack of creativity and innovation in the management of ADD for community empowerment.

The inhibiting factor in the management of ADD in subsequent empowerment is the lack of community self-help. From the results of the study, Langensari village community self-help is considered to be very lacking, even though the community self-sufficiency is a legitimate Village Original Income (PADes). The lack of community self-help is a reflection of the level of welfare of the village community, which is still considered lacking.

I have seen from the majority of the livelihoods of the Langensari villagers who, as agricultural laborers, have an impact on the level of community selfsufficiency in village development. This phenomenon is not by the purpose of ADD, one of which is to encourage increased community self-sufficiency. This condition shows that the unsuccessful management of ADD in Langensari village resulted in the lack of community self-help.

\section{CONCLUSION}

Management of Village Fund Allocation (ADD) in community empowerment in Langensari Village, Karangtengah Subdistrict, Cianjur Regency shows that a portion of ADD funds for community empowerment is used for operational costs of the village government and BPD so that the use of ADD is not by its designation. In ADD planning, the level of community participation in village deliberations is quite high. However, in the process of capturing these aspirations, it is constrained by the lack of public education, so that community aspirations tend to be of physical development (village infrastructure), they should prioritize community empowerment.

In ADD budgeting, there was a discrepancy with Cianjur Regent Regulation No. 5 of 2015 concerning Guidelines for the Management of Village Fund Allocation for Cianjur Regency in 2015. Where the ADD funds for the operation of the Village Consultative Body (BPD) which should have been included in the RPD for Village Government Operations but instead were included in the RPD for community empowerment. This reduces the portion of $70 \%$ for community empowerment. 
The disbursement and distribution mechanism of ADD is already by regulations governing village financial management, namely Minister of Domestic Affairs Regulation No. 113 of 2014 concerning Village Financial Management. Terms and conditions for ADD disbursement and disbursement have not yet been fulfilled, so payment and distribution cannot be implemented.

In general, the use of ADD based on the target of surgery has been going well even though in various fields, the use of ADD is still not optimal. This can be seen from the ADD program that has been running since 2007 which has not shown maximum results such as the absence of an increase in Village Original Revenue (PADes), the not yet being formed of Village Owned Enterprises (BUMDes) and also not, however, is optimal of community self-sufficiency.

Supervision in the ADD program implementation occurs from 3 types of control. First, functional monitoring, namely surveillance carried out by the government of Cianjur Regency and Karangtengah District in the form of reporting, should be done 2 (two) times. But the implementation is only done once a year. Second, inherent supervision, namely supervision carried out by direct superiors through the structure of the village government organization, in this case, carried out by the Village Head, village apparatus, and each chair implementing activities.

Third, direct supervision by the community; in fact, there has not been direct supervision by the city in the management of ADD. This fact occurs because of the community's lack of understanding of the ADD program.

The ADD liability consists of two types of debt. First, Administrative Responsibility and Second, Direct accountability to the community has not yet occurred because openness by the village government as the manager of ADD to the community in the form of information on the use of ADD funds is very low.

Supporting factors in the management of ADD in community empowerment. First, the high level of community participation is one factor that supports the management of ADD, especially in the planning process. Secondly, the culture of community cooperation is the village's potential in managing ADD in community empowerment. Third, functional supervision by the District and District Governments can improve the discipline of village governments in managing ADD.

The inhibiting factor in the management of ADD in community empowerment is human resources (HR). The low human resources of the village and the villagers are the main obstacles to ADD control because in the planning, implementation, and accountability processes, therefore it is necessary to have qualified human resources in the ADD management process. Also, the lack of supervision from the community in managing ADD is also an inhibiting factor. 


\section{REFERENCES}

1. Statistics Indonesia 2016 (https://www.bps.go.id/brs/view/id/1229).

2. Cianjur Regent Regulation Number 5 Year 2015 concerning Guidelines for the Management of Cianjur Regency Village Fund Allocation in 2015.

3. Minister of Home Affairs Regulation Number 113 Year 2014 Village Financial Management.

4. Law Number 6 of 2014 concerning Villages.

5. Prasojo, E. (2003). People and Society Empowerment: Perspectives on Building Public Participation. Public Scientific Journal, IV(2), 10-24.

6. Sugiyono (2009). Quantitative \& Qualitative Research Methods. Bandung: Alpabeta.

7. Suharto, E. (2005). Building a Community Empowering People. Bandung: Refika Aditama.

8. Sumaryadi, I. N. (2005). Autonomous Regional Development Planning and Community Empowerment. Jakarta, Citra Utama.

9. Wahjudin, S. (2011). Integrated Village Planning. Banda Aceh: Reinforcement Action and Development.

10. Widjaja, H. A. W. (2004). Village Autonomy Is Round and Whole Autonomy. Jakarta: Raja Grafindo Persada. 